\title{
Globalization and Language Hegemony
}

\author{
Indrawati $^{1,2, *}$, Sri Samiati Tarjana ${ }^{3}$, Joko Nurkamto $^{3}$ \\ 1 English Department, Universitas Negeri Semarang (UNNES). \\ 2 Doctoral Candidate of Linguistics, Universitas Sebelas Maret Surakarta (UNS) \\ 3 Faculty of Cultural Studies, UNS \\ *e-mail: indrawatisudarmono1@gmail.com
}

\begin{abstract}
In view of the cultural aspect, the national identity of Indonesia is the manifestation of cultural values that develop in all aspects of life with unique characteristics differentiating Indonesia from other countries. As a pluralistic country, Indonesia has 34 provinces with more than 16.000 islands of varied cultures. All of which have the power to integrate or disintegrate Indonesia's national unity. Inevitably, the world is changing in a process of globalization toward creating a new borderless big village with consequences 1 ) less government power; 2 ) liberalism; 3) free market economy; 4) western culture hegemony; and many others. Globalization is deemed catastrophic toward Indonesian traditional values.

This paper argues that globalization, on the contrary, brings the opportunity to see the reality of language use in that between English and Indonesian pragmatic apology utterances, both expressive speech acts show similarity in apology features. This paper wants to see whether globalization affects local identity in the context of language use. This paper analyzed apology utterances in Friends TV Series as western representation and utterances found in Office Boy TV Series as Indonesian representation. It is a descriptive qualitative study with content analysis adopted from Spradley in Santoso (2017). The finding shows that apology utterances both English and Indonesian realized universal features of apology that is IFID, Responsibility, Explanation, Repair, Forbearance, Addressed, Phatic, and Interjection. In conclusion, there is no language hegemony. If one considers similarities rather than differences, one will get a deeper insight into languages that will broaden one's view of language.
\end{abstract}

\section{Keywords}

apology utterances, globalization, national identity, pragmatic aspect, universal features

Citation: Indrawati, Tarjana, S.S., Nurkamto, J.: Globalization and Language Hegemony. In. D. Ekawati, et al (eds.): Proceeding of The American Studies International Conference 2018, Vol. 2. pp. 65-70 UGM Digital Press Social Sciences and Humanities, Yogyakarta (2019).

Published: May, 2019

\section{Introduction}

Education is impacted by the process of globalization. Schools continue to prepare students for citizenship could need roles beyond national borders caused by the realities of global interconnections. The processes of globalization are not known. They were in place hundreds of years ago as local borrowing and adapting of ideas, language, foods, textiles, technologies, and other products gradually gave way to regional interconnectedness through trade, conquest, and cultural 
diffusion (Raskin et al., 2002). In language, English and Indonesian language apology carry similar features.

\section{Theoretical Framework}

\subsection{Hegemony}

Gramsci's $(1971,1977,1991)$ writing has been used largely in the sense that people use the notion of hegemony to media texts and cultural practices. Hegemony usually is understood along with the term ideology. Ideology facilitates understanding of how certain ideas are able to control thinking in society, the ways that these ideas maintain power and control over society all together is hegemony (Hall: 1986 a, 1986 b).

Hegemonic ideologies are not imposed, but rather embraced by society. Hegemony recognizes that there is dissimilarity in wealth and power and seek to show how those inequalities have been maintained or challenged in the sphere of culture (Lears, 1985, p. 572). The above statement is mostly related to certain phenomena in society, such as belief, perceptions, practices of certain values denoting prevailing behavior like materialism, individualism, equality and many others.

This study pertains the term hegemonic ideology with the meaning of language domination over another language. For instance, English whose role and use are strategic and influential for use in international relations, business, and the industry is not necessarily dominating Indonesian or weaken the Indonesian language.

The fact is even something of constructive and beneficial. As clearly seen, language expands and grows with the advanced technology and the use of media globally. Language takes features of other language and on the other hand, the language that has taken the other feature language let other language does the same. The process of borrowing, coining, or adapting the language feature of others to one's language could even enrich the language that mirrors the richness of vocabulary.

For instance, English borrows Indonesian words like gamelan, gong, durian, rambutan, and others; and in turns, the Indonesian language is made more varied with English words that become words in Indonesian vocabularies, like names of fruits, cutlery, tools, other words of various functions.

The following is apologizing of English and Indonesian which were analyzed to see their linguistic features. Apologizing is a common feature of the daily language used in people's communication both in spoken and written. However, it is a complex phenomenon and difficult to recognize as it takes into account various social, psychological, linguistic, and paralinguistic aspects in its real usage. An apology is a speech act addressed to B's face needs and intended to remedy an offense for which A takes responsibility, and thus to restore equilibrium between $\mathrm{A}$ and $\mathrm{B}$ (where $\mathrm{A}$ is the apologizer, and $\mathrm{B}$ is the person offended).

An act of apology is a post-event speech act signifying a violation of social norms (Spencer-Oatey, 2008). In regards the face needs of the addressee and is often described as a face supportive act (Holmes, 1995). The speaker realizes the violation and takes responsibility for it while at the same time remedies the relationship with the hearer being offended.

Goffman (1971) mentioned apology as remedial interchange using speech acts which Holmes (1990) considered multifunctional both linguistic and nonlinguistic features in its realization. An apology is considered a negative strategy as it expresses respect rather than solidarity or friendliness. It is different from strategies to show compliment and greeting aiming at showing solidarity and friendliness (Holmes, 1990, 1995) as positive politeness.

As the strategy of politeness, Brown, and Levinson (1987) and Holmes (1990) refer apology as the speech act indicating various levels of politeness involving face management. In the case of apology as negative politeness, it concerns with the damage caused by the offense done by the speaker to the hearer (Deutschmann, 2003) in Ogeirman (1984). Yet, Larina (2003) sees an apology as positive politeness as the Speaker repairs the mistake or offense to the hearer. Speaker seeks for maintaining good relationship between Speaker and Hearer.

An apology is the convivial speech act type whose illocutionary goal is similar to the social goal that is keeping harmony between Speaker and Hearer, which inherently means polite (Leech, 1983). The concept of apology seems to be universal, yet, its operation and interpretation maybe culture-specific, since an offense that requires an apology in one culture may not require an apology in another. As well, the frequency and type of apology vary significantly from culture to culture (Cohen \& Olshtain 1981; Olshtain, 1989; Vollmen \& Olshtain 1989). 
Apologetic expression to maintain harmony is used in various strategies. Blum-Kulka, House and Kasper (1989, p. 290) in Jucker (2008, p. 231) assert the following five strategies with their illustrations:

IFID: I'm sorry

RESPONSIBILITY: I missed the bus

EXPLANATION: There was a terrible traffic jam

REPAIR: Let's make another appointment

FORBEARANCE: I'll make sure that I'm here on time

Indonesian apology expression calls for strategies of addressed, phatic, and interjection. Apologizing in Indonesia also calls for nonlinguistic aspects such as age, gender, social distance and ranking of imposition.

In relation to addressed, phatic, and interjection, people sometimes use more than one strategy. They may merge one strategy with another. (Choer, 2010, p. 97) mentioned that first, people generally apply IFID followed by addressed, e.g." maaf ya pak..."; second, people apply IFID with phatic expression in different conditions. To the person of different power, distance and Rank of Imposition, e.g. Mohon maaf yang sebesar-besarnya, ya pak, or e.g. Maafya bro, sis; third people apply IFID with interjection expression e.g. Oke, maaf ya, hehe.

Inquiring into apology has been conducted lately. Park and Guan (2006) discussed different impacts of apology among cultures. Spencer-Oatey (2008) stated that Japanese people are the ones who realized the act of apology more frequently than other people in various cultures.

The study of Indonesian apology has been conducted by many researchers. Indonesian students applied eight strategies that are (1) IFID, (2) explanation or account of situation, (3) acknowledgment of responsibility with three subcategories (a) accepting responsibility; (b) explicit self-blame; (c) denial of fault, (4) an offer of repair, (5) a promise of forbearance, (6) addressed, (7) phatic (approval), (8) interjection (show emotion) Winda (2013) and Wouk (2006) also conducted the study of Lombok apologies.

The study of apology which sees apology across cultures is possible to be conducted in order to see the differences of each culture related to aspects of prevailing linguistic and nonlinguistic.

As the present study suggests, the study analyzes apology in dialogues on the TV sitcoms. The two apology speech acts, English and Indonesian are analyzed. The apology expressions are taken from Friends, English language TV Sitcom and from Office Boy, Indonesian language TV Sitcom. The result of this study is expected to have significant pedagogical implication for EFL or ESL teaching with respect to L1 as the learners' native language.

\subsection{Ideology in Media}

Television is crucial in preserving ideology in society. Ideology is the study of ideas and knowledge (Hall, 1986, p. 29 as cited in Marshall, 2007). Ideology is the mental frameworks: the language, the concepts, categories, imagery of thoughts and the system of representation that are used by the social classes to make sense of, define, figure, and render intelligible the society works.

The ideology which is dominant functions as system about the world that supports the dominant social class. It controls and solves problems and returns the unstable social condition into a stable one to gain unity and conformity of knowledge (Butler, 207, p. 446). Television sitcoms of Friends and Office Boy serve as discourses popularized through TV as media. These discourses reveal an image of the world that TV producers plan to show to the public or TV viewers. These discourses are very significant as the way to educate people through TV (Television). Television as media culture supports hegemonic class of society which through TV Sitcom, people's lifestyle, social norms an behavior as shown through TV Sitcom characters are presented, preserved, and widely spread.

Friends TV Series

Friends are produced by NBC as TV prime time show for 10 seasons in 236 episodes from 1994 to 2004. The film shows six characters as friends: Monica, Rachel, Phoebe, Joey, Chandler, Ross. They were interacting and growing into maturity in pursuing love and career in New York, US.

Office Boy TV Series

Office Boy is produced by MNC Media/RCTI in 2006. The film shows eight people who interact within the office in the media sphere. Although Taka, Hendra, Gusti, and Sasha are bosses in HRD section in the office, the other three office boys and cleaning service: Saodah, Sayuti, Ismail, and Susi interact to each other in the informal register. Each episode presents a guest star who involves in the plot consistently. 


\section{Methods}

This study analyzed dialogs in English Friends sitcom and Indonesian Office Boy sitcom to see apology strategy realized in English and Indonesian. The dialog of Friends sitcom consists of eight apology speech acts realized in the themes of friendship and courtship. The dialog of Office Boy sitcom consists of eight apology speech acts realized in themes of The Ruin Holiday, Who Sayuti Picks?, and When Hendra Treats a Chick. The above apology strategies are analyzed in the realization of IFID, responsibility, explanation, repair, forbearance, addressed, phatic, interjection.

The data are analyzed based on the criteria of apology strategy (Blum-Kulka, 1984) and Indonesia apology (Choer, 2010, p. 97).

\section{Results and Discussion}

\section{English Apology Speech Acts}

I'm sorry buddy, but I don't think I'm gonna be able to make it.

I'm sorry really. I'm so embarrassed. Really. I'm a pretty nice guy. Just ask my parole officer. Apparently, I'm not a funny guy.

I'm sorry. I'm sorry. I should have told you.

I'm sorry. I don't mean that. I want you to be happy. But only with me. No that's not fair. Uuuh.. who cares, leave him. Ooh I don't mean that. Yes I do... ... ... I'm sorry ooh I think I probably go.

I'm sorry. I'm sorry. If you want you key back, I totally understand.

I'm sorry honey, but we are gonna take you shopping. It's gonna be fine.

I'm so sorry. I really really am sorry.

Yes, I'm sorry. I have never met boyfriend's parents before.

Indonesian Apology Speech Acts

Maapin mpok, badan saya kagak enak banget nih... duh kan mpok sudah saya kasih duit 10 ribu.

Sorry mpok, I don't feel well. Haven't I returned ten thousand rupiahs?

Maaf Pak Taka.. kalau boleh hari ini saya mau ijin pulang cepat, soalnya saya ada janji mau makan... tolong ya Pak

I'm sorry Mr. Taka, can I leave earlier, I have an appointment.. please Sir..

Maaf Pak Taka, saya tidak bermaksud menyindir.

Sorry Mr. Taka. I don't mean it.

Maaf banget ya.. udah marah-marah.. jadi nggak enak.. maaf lo.

So sorry.. I got mad at you. Really sorry.

Maaf Pak Taka, uang kas kantor kita saat ini tidak mencukupi untuk...

Sorry Mr. Taka, we don't have enough money this time.

Sori Taka. Sebetulnya saya mau minjemin duit gratis sama lo, tapi sekarang ini gue lagi butuh uang segera. Sorry Taka. Actually I want to borrow it to you for free, but I really need some money this time.

Maaf Pak, kemaren ada pembayaran...

Sorry Sir, yesterday we had to pay...

Maaf Pak, prosedurnya sangat rumit.

Sorry Sir, the procedure is complicated. 
Table 1 shows the apology strategy employed on TV Sitcom Friends, then Table 2 describes the apology strategy on TV Sitcom Office Boy

Table 1 and Table 2 Apology Strategy on TV Sitcom Friends and Office Boy

Table 1 Apology Strategy on TV Sitcom Friends

\begin{tabular}{|c|c|c|c|c|c|c|c|c|}
\hline \multirow{2}{*}{$\begin{array}{l}\text { Sentence } \\
\text { Number }\end{array}$} & \multicolumn{8}{|c|}{ Apology Strategy } \\
\hline & IFID & Responsibility & Explanation & Repair & Forbearance & Addressed & Phatic & Interjection \\
\hline 1 & $\mathrm{v}$ & & $\mathrm{v}$ & & & $\mathrm{v}$ & & \\
\hline 2 & $\mathrm{v}$ & $\mathrm{v}$ & $\mathrm{v}$ & & $\mathrm{v}$ & & V & \\
\hline 3 & $\mathrm{v}$ & $\mathrm{v}$ & & & & & & \\
\hline 4 & $\mathrm{v}$ & $\mathrm{v}$ & $\mathrm{v}$ & $\mathrm{v}$ & $\mathrm{v}$ & & & \\
\hline 5 & $\mathrm{v}$ & & & $\mathrm{v}$ & $\mathrm{v}$ & & & \\
\hline 6 & $\mathrm{v}$ & & & $\mathrm{v}$ & $\mathrm{v}$ & $\mathrm{v}$ & & \\
\hline 7 & $\mathrm{v}$ & & & & & & & \\
\hline 8 & $\mathrm{v}$ & $\mathrm{v}$ & & & & & & \\
\hline
\end{tabular}

Table 2 Apology Strategy on TV Sitcom Office Boy

\begin{tabular}{|c|c|c|c|c|c|c|c|c|}
\hline \multirow{2}{*}{$\begin{array}{l}\text { Sentence } \\
\text { Number }\end{array}$} & \multicolumn{8}{|c|}{ Apology Strategy } \\
\hline & IFID & Responsibility & Explanation & Repair & Forbearance & Addressed & Phatic & Interjection \\
\hline 1 & $\mathrm{~V}$ & $\mathrm{~V}$ & & & & $\mathrm{~V}$ & & $\mathrm{~V}$ \\
\hline 2 & $\mathrm{v}$ & $\mathrm{v}$ & $\mathrm{v}$ & & & $\mathrm{v}$ & $\mathrm{v}$ & \\
\hline 3 & $\mathrm{v}$ & $\mathrm{v}$ & & & & $\mathrm{v}$ & & $\mathrm{v}$ \\
\hline 4 & $\mathrm{v}$ & & & & & & $\mathrm{v}$ & \\
\hline 5 & $\mathrm{v}$ & $\mathrm{v}$ & $\mathrm{v}$ & & & $\mathrm{v}$ & & \\
\hline 6 & $\mathrm{v}$ & $\mathrm{v}$ & $\mathrm{v}$ & & & $\mathrm{v}$ & & \\
\hline 7 & $\mathrm{v}$ & $\mathrm{v}$ & & & & $\mathrm{v}$ & & \\
\hline 8 & $\mathrm{v}$ & $\mathrm{v}$ & & & & $\mathrm{v}$ & & \\
\hline
\end{tabular}

English apology speech acts mainly apply IFID in the form of I'm sorry, I'm sorry really, I am sorry; using intensifier really, duplication to show stress, I'm so sorry; showing intensifier, I really really am sorry; duplication. Besides that, speech acts use addressed features like honey and buddy.

Responsibility is applied in apology sentences number $1,2,3,4$, and 8 . The explanation is realized in sentences 1, 2, 4. Repair is used in sentences 4, 5, 6. Forbearance is applied in sentences 2, 4, 5, and 6 . Addressed is used in sentences 1 and 6. Phatic is realized in sentence no. 2 and none interjection exists on the sentences.

Indonesian IFID is applied in all sentences. Responsibility is realized in each sentence. The explanation is used in sentences 2, 4,5, and 6. Repair exists in sentence 8. Forbearance does not exist. Addressed is used in every sentence except sentence number 4 . Phatic is on sentence 2 and 4 . Interjections are on the 1, 4, and 8.

\section{Conclusions}

Apology speech acts found on Friends TV Sitcom applied eight IFID, and five Responsibility, three Explanation, three Repair, four Forbearance as the main feature in apology speech acts. The feature of Addressed is used only two and Phatic only one proves that these features considered less important.

In apology strategy found in Office Boy TV Sitcom, IFID and Responsibility are fully applied; whereas explanation is only three, Repair is only one, show that IFID and Responsibility are the main features. The feature of Addressed, Phatic, and Interjection are varied in common. Addressed is used in seven sentences. Phatic is applied in two sentences. An interjection is realized in three sentences.

These findings show that related to the main feature as IFID, Responsibility, and Explanation, there is no significant difference between English apology and Indonesian apology. However, the use of three features 
Addressed, Phatic, Interjections, there is a significant difference, since English apology applies three features; whereas Indonesian apology applies twelve features.

The data show that English and Indonesian apology speech acts realized main apology features, that are IFID, Responsibility, and Explanation. English and Indonesian apology are similar in three main features. Whereas, English and Indonesian apology differ in the use of Addressed, Phatic, and Interjection. In conclusion, the pragmatic ability could develop through universal pragmatic knowledge because L1 could be transferred in learning L2. It refers to the features of Addressed, Phatic, and Interjection; learners need to gain knowledge of three linguistic features related to other cultural backgrounds. The result shows what scholars say that language carries universal features.

\section{Acknowledgments}

The writer would like to express her gratitude to the supervisors Sri Samiati Tarjana and Joko Nurkamto for their sincere advice and supports. The writer also expresses her gratitude to Universitas Sebelas Maret, Surakarta for giving opportunity to develop her knowledge in the field of Pragmatics.

\section{References}

1. Blum-Kulka, S \& Olshtain., E. (1984). Request and Apologies. A cross-cultural study of speech act realization patterns (CCSARP). Applied Linguistics, 5 (3), 196-213.

2. Brown, P \& Levinson, S.C. (1987). Politeness: Some Universals in Language Usage. Cambridge: Cambridge University Press.

3. Choer, A. (2010). Kesantunan Berbahasa. Jakarta: Rineka Cipta.

4. Gramsci, A. (1991). Prison Notebooks. New York: Columbia University Press.

5. Gramsci, A. (1991). Selections from the Prison Notebooks. London: Lawrence and Wishart.

6. Gramsci, A. (1997). Selections from the Political Writings. New York: International.

7. Hall, S. (1986). Gramsci's Relevance for the Study of Race and Ethnicity. Journal of Communication Inquiry. 10.5-27.

8. Hall, S. (1986) b. The Problem with Ideology-Marxism without Guarantee. Journal of Communication Inquiry. 10.28-44.

9. Jucker, A.H. \& Taavitsainen, I. (2008). Speech act in the history of English. Amsterdam: John Benjamins Publishing Company. p. 231

10. Lears, T.J.J. (1985). The Concept of Cultural Hegemony: Problems and Possibilities. The American Historical Review. 90. 567-593.

11. Leech, G. (1983). Principles of Pragmatics. London: Longman.

12. Oatey, H.S. (2000). Culturally Speaking: Culture, communication and politeness theory. London: Continuum International Publishing Group.

13. Raskin, P, Banuri, T, G, Gilberto, et al. (2002) Great Transition: The Promise and Lure of the Times Ahead. SEI PoleStar Series Report no. 10. Boston: Stockholm Environment Institute, Tellus Institute. Retrieved from http://www.gtinitiative.org/documents/Great_Transitions.pdf (1 February 2007)

14. Winda SW, A. (2014) "Apologizing Strategies Realization of Indonesian: A Case Study of the University of Kuningan Students" EnglishReview: Journal of English Education. Vol 2 (2) pp. 200208

15. Wouk, F. (2006). “The Language of Apologizing in Lombok, Indonesia.” Journal of Pragmatics Vol 38. pp. $1457-1486$ 